\title{
TELEGRAPHY FIRST USED HERE IN 1862
}

By Henry T. Rice

In reviewing Des Moines' rich heritage of progress and achievements, one of the major milestones in local history was the opening of the first telegraph office here in 1862 , it was pointed out by R. S. Carpenter, local Western Union superintendent.

The telegraph has played an all-important part in the development of this community for 88 years.

In the early days of this city the "lightning wires," as the telegraph lines were called, were the only means of annihilating time and the space separating communities spread across the nation. The eye-shaded telegraph operator of that era, huddled over his Morse key tapping out messages, is history now, but still among the boyhood recollections of older people.

The second and third decades of this century saw the rise of printing telegraphy, in which machines with typewriter-like keyboards were used to send telegrams and the messages arrived automatically in printed form. Since there were not enough wires to connect all places directly with all others, telegrams were transmitted from the point of origin to a relay city. There they were gummed to telegram blanks, sorted by routing clerks and carried by girls to operators. The messages were then retyped on telegraph machines to transmit them on, usually to other relay points, before they reached their destinations.

Now a new ultra modern era has arrived and all of these time-consuming steps have been eliminated by a nation-wide, high-speed switching system. In the new system each telegram is typed once at the point of origin, and then automatically flashes to its destination with almost magical speed and efficiency.

Des Moines has benefited greatly from Western Union's $\$ 80,000,000$ mechanization and plant improvement program. The local telegraph office is connected directly 
with a huge "electrical brain" in Minneapolis, the clearing house for all telegrams to and from this area, and one of a nationwide network of high speed switching centers. The big selective switching center there flashes telegrams automatically and with great speed between all parts of the country and Western Union offices in Iowa, Minnesota, Wisconsin, North Dakota and South Dakota.

\section{A Maze of Electrical Apparatus}

The ultra modern center, important in providing our food, clothing and other needs, is comprised of aisle after aisle of equipment and a maze of electrical apparatus. It covers thousands of feet of floor space and includes more than 3,000 miles of wires and over a million soldered wire connections.

An operator transmitting a message from the local Western Union office types two "call letters" at the beginning of each telegram. These call letters cause the electrical brain at the switching center in Minneapolis to select the proper circuit and automatically flash the telegram to its destination.

In the case of a telegram addressed to Cleveland, Ohio, for example, the local operator here will type the letters "CL", representing the destination on a typewriter-like machine. These letters flash to the switching center at Minneapolis where the electrical brain automatically connects the telegram with the Cleveland, Ohio, circuit and speeds it to that city where it is received in printed form ready for delivery.

To provide the many circuits needed between all centers in the nationwide switching system, more than 1,500,000 miles of carrier circuits have been placed in operation. Each carrier system is capable of carrying 288 messages simultaneously over a pair of wires. Additional carrier systems are now being completed between cities throughout the country.

To meet the heavy volume communication needs of the future, Western Union also has built a microwave 
radio beam telegraph system over which more than 2,000 telegrams may be sent simultaneously in both directions. In this system radio towers 30 to 50 miles apart have replaced the familiar telegraph poles and wires. Impervious to snow, ice and other natural hazards, the radio beam system is providing telegraph facilities of great reliability.

An important problem facing the telegraph industry today is the burden of the Federal tax of 25 per cent on telegraph users. This wartime tax was levied to discourage the use of the telegraph at a time when it was necessary to restrict the flow of unessential traffic in favor of vital war messages. In 1948 this destructive tax amounted to $\$ 40,000,000$ - a figure closely approaching the government subsidy of air mail, one of Western Union's chief competitors. Vigorous efforts are being made to effect the elimination of this tax, which is higher than that for night clubs, theaters, furs and cosmetics.

\section{PRESERVATION OF HISTORIC SITES}

The Eighty-First congress passed and the president signed, a bill creating a National Trust for Historic Preservation in the United States. The primary purpose of the National Trust will be to facilitate public participation in the preservation of sites, buildings, and objects of national significance or interest. It will encourage preservation on every level, national, regional, state, and local. It is also empowered to receive and administer for the public benefit buildings and sites worthy of permanent preservation, which may be presented to it.

The National Trust will be administered under the general direction of a board of trustees composed of the attorney general of the United States, the secretary of the interior, the director of the National Gallery of Art, and six other American citizens chosen by the executive board of the National Council for Historic Sites and Buildings. 
Copyright of Annals of Iowa is the property of State of Iowa, by \& through the State Historical Society of Iowa and its content may not be copied or emailed to multiple sites or posted to a listserv without the copyright holder's express written permission. However, users may print, download, or email articles for individual use. 